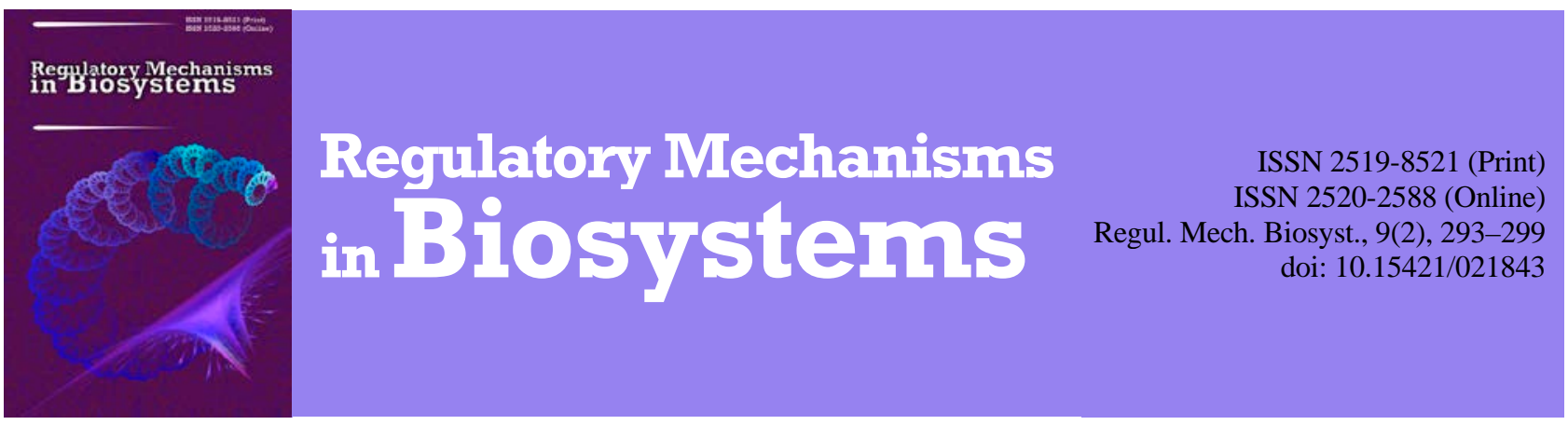

\title{
Dynamic of accumulation and redistribution of various carbohydrate forms and nitrogen in organs of tomatoes under treatment with retardants
}

\author{
V. V. Rogach, O. O. Kravets, O. I. Buina, V. G. Kuryata \\ Vinnytsia Mykhailo Kotsiubynskyi State Pedagogical University, Vinnytsia, Ukraine
}

Article info

Received 17.02.2018

Received in revised form 26.03.2018

Accepted 30.03.2018

Vinnytsia Mykhailo Kotsiubynskyi State Pedagogical University, Ostrozhskogo st., 32,

Vinnitsa, 21000, Ukraine. Tel.: +38-098-594-48-32. E-mail: rogachv@ukr.net
Rogach, V. V., Kravets, O. O., Buina, O. I., \& Kuryata, V. G. (2018). Dynamic of accumulation and redistribution of various carbohydrate forms and nitrogen in organs of tomatoes under treatment with retardants. Regulatory Mechanisms in Biosystems, 9(2), 293-299. doi:10.15421/021843

The regulation of plant growth and development under application of antigibberellin compounds is accompanied by changes in the donor-acceptor system that in turn affects the accumulation and redistribution of carbohydrates and nitrogencontaining compounds. We studied the influence of tebuconazole 0.025\% (EW-250) and 0.05\% and 0.07\% esphon (2-CEPA) on growth processes, leaf apparatus and content of various carbohydrate forms and total nitrogen content in vegetative organs of tomato hybrids Bobkat and Solerosso. A field-based micro-trial setup was established from 2013 to 2017. The plants were treated via foliar spraying with aqueous solution of retardants at the time of initiation of budding. Phytometric measurements were determined every 10 days, the content of various carbohydrate forms and total nitrogen in organs of plants was determined by using biochemical methods in a fixed dry material (the content of sugars and starch - by iodometric method, and the total nitrogen content - by Kjeldahl). It was found that both retardants reduced the linear growth of tomato plants. The results indicate that 2-CEPA treatment significantly decreased the plant height of both hybrids. Application of drugs increased the number of leaves per plant. The leaf dry matter weight increased, the most significant effect was created by EW-250. The leaf area of the retardant-treated tomatoes hybrid Solerosso increased and decreased in the hybrid Bobcat. Application of antigibberellin compounds intensified the outflow of sugars and remobilization of starch in roots and stems of both tomato hybrids. The content of starch, reducing and non-reducing sugars in leaves of hybrid Solerosso was higher after EW-250 treatment. 2-CEPA increased the content of reducing form of sugars, and EW-250 increased non-reducing form in the hybrid Bobkat. EW-250 intensified the accumulation of carbohydrates in fruits due to reducing sugars in both tomato hybrids, whereas 2-CEPA reduced their content compared with control. Growth inhibitors increased the starch content in fruits at the beginning of vegetation and intensified its reutilization at the end. This process was most intensive was in variant of EW-250treated plants regardless of hybrids. We proved that there was a clear tendency to decrease the ratio of sugar content to starch in almost all organs of both tomato hybrids during the growing season. The most significant was the reduction of this ratio after EW-250 treatment. At the fruitification phase, the proportion of starch in retardant-treated plants increased compared to the control. The increased accumulation of carbohydrates in tomato fruits treated with EW-250 caused an increase in the average weight of the fruit. We have found that the total nitrogen content in vegetative organs decreased in the control and in the experimental variant of both tomato hybrids during vegetation. EW-250 accelerated the outflow of total nitrogen from roots and stems and increased its content in leaves. This drug retarded the accumulation of this element in fruit. Such changes in the dynamics of total nitrogen under the influence of tebuconazole resulted in enhanced formation of fruit on tomato plants. We concluded that the antigibberellin compounds EW-250 and 2-CEPA due the action on growth processes and leaf apparatus of tomato plants, changed the character of donor-acceptor relation through an increase in outflow of plastic substances from vegetative organs to fruits, which optimized the crop production.

Keywords: Solanum lycopersicum; antigibberellin compounds; leaf apparatus; sugar; starch; total nitrogen; productivity

\section{Динаміка накопичення та перерозподілу різних форм вуглеводів та азоту в органах рослин томатів за дії ретардантів}

\author{
В. В. Рогач, О. О. Кравець, О. І. Буйна, В. Г. Кур’ята \\ Вінницький державний педагогічний університет імені Михайла Кочюбинського, Вінниия, Украӥна
}

Регуляція росту та розвитку рослин за допомогою антигіберелінових препаратів супроводжується змінами у донорно-акцепторній системі, що впливає на накопичення та перерозподіл основних пластичних речовин (вуглеводів і азотумісних сполук). Досліджували вплив $0,025 \%$ тебуконазолу (EW-250) та 0,05\% і 0,07\% есфону (2-ХЕФК) на ростові процеси, листковий апарат та вміст різних форм вуглеводів і загального азоту у вегетативних органах томатів гібридів Бобкат і Солероссо. Польові дрібноділянкові досліди закладали в 2013-2017 роках. Рослини обробляли у фазу бутонізації водними розчинами ретардантів за допомогою ранцевого обприскувача. Фітометричні показники визначали 
кожні 10 діб, вміст різних форм вуглеводів і загального азоту в органах рослин визначали біохімічними методами у фіксованому сухому матеріалі (вміст цукрів і крохмалю визначали йодометричним методом, а вміст загального азоту - методом К'єльдаля). Обидва препарати зменшували лінійні розміри рослин томатів. Найсуттєвіше зменшення висоти в обох гібридів спостерігали після застосування 2-ХЕФК. Препарати збільшували кількість листків на рослині. Маса сухої речовини листків зростала тільки після обробки ЕW-250. Площа листків за дії ретардантів зростала у гібриду Солероссо та зменшувалася у гібриду Бобкат. Застосування антигіберелінових препаратів посилювало відтік цукрів та реутилізацію крохмалю $з$ коріння та стебел обох гібридів томатів. У листках гібриду Солероссо вміст крохмалю, редукуючих і нередукуючих цукрів став вищим після застосування EW-250. У гібриду Бобкат 2-ХЕФК зумовлювала збільшення вмісту редукуючих форм цукрів, a EW-250 - нередукуючих. EW-250 посилював накопичення цукрів у плодах за рахунок редукуючих форм в обох гібридів томатів, тоді як 2-ХЕФК знижувала їх вміст порівняно 3 контролем. Інгібітори росту підвищували вміст крохмалю у плодах на початку вегетації та інтенсифікували його реутилізацію наприкінці. Найшвидше це відбувалося після обробки рослин томатів EW-250 незалежно від гібриду. Впродовж вегетації спостерігали тенденцію до зменшення відношення суми цукрів до крохмалю практично в усіх органах обох гібридів томатів. Найсуттєвіше зменшення цього співвідношення зафіксовано після обробки рослин томатів EW-250. Під час появи плодів частка крохмалю у рослин, що зазнали дії ретардантів, була більшою, ніж у контролі. Посилене накопичення вуглеводів плодами рослин томатів, оброблених EW-250, зумовило зростання середньої маси одного плоду. Впродовж вегетації відбувалося зменшення вмісту загального азоту у вегетативних органах як у контролі, так і в досліді в обох гібридів томатів. EW-250 пришвидшував відтік загального азоту з коріння та стебел і збільшував його вміст у листках. За дії триазолового препарату відбувалося уповільнення накопичення цього елемента у плодах. Такі зміни у динаміці загального азоту за впливу тебуконазолу зумовили посилену закладку плодів на рослинах томатів. Антигіберелінові препарати ЕW250 та 2-ХЕФК, впливаючи на ростові процеси та листковий апарат рослин томатів, посилювали відтік пластичних речовин від вегетативних органів до плодів, що підвищувало продуктивність культури.

Ключові слова: Solanum lycopersicum; антигіберелінові препарати; листковий апарат; цукри; крохмаль; загальний азот; продуктивність

\section{Вступ}

Вивчення закономірностей функціонування донорно-акцепторної системи рослин і розроблення засобів екзогенної регуляції переміщення потоків асимілятів, спрямування їх до господарсько-важливих тканин і органів - актуальні завдання сучасної фітофізіології. Застосування ретардантів та етиленпродуцентів дає можливість змінювати напруженість донорно-акцепторної системи рослини внаслідок регуляції процесів росту, фотосинтезу та перерозподілу потоків пластичних речовин із вегетативних органів на потреби карпогенезу (формування та ріст плодів), що в кінцевій меті оптимізує продукційний процес у сільськогосподарських культур (Singh et al., 2017).

У рослин батату обробка триазолпохідним ретардантом паклобутразолом зумовлювала зростання площі листкової поверхні та підвищувала вміст редукуючих і нередукуючих цукрів у листках на 3,8\%. За дії препарату також зростав вміст деяких амінокислот і підвищувалася продуктивність культури (Үооyongwech et al., 2017). Обробка паклобутразолом рослин манго збільшувала вміст усіх форм цукрів у плодах і підвищувала врожайність культури (Sarker et al., 2016). Цей же препарат підвищував вміст вуглеводів у рослин рису (Xiang et al., 2017). Застосування паклобутразолу на рослинах каноли у фазу бутонізації гальмувало ростові процеси та посилювало накопичення розчинних цукрів, сахарози та крохмалю у стеблах і плодах з одночасним зменшенням їх вмісту в корінні. Ретардант підвищував ефективність утилізації вуглеводів рослинами, що позитивно вплинуло на урожайність культури (Hua et al., 2014). Іншим триазолпохідним препаратом - уніконазолом - обробляли насіння соєвих бобів. Спостерігали зменшення площі листкової поверхні та підвищення продуктивності культури (Yan et al., 2015). За дії цього ж ретарданту відбувалося збільшення вмісту крохмалю у рослин Landoltia punctata (Liu et al., 2014).

Застосування суміші паклобутразолу та хлормекватхлориду на рослинах пажитниці багаторічної зменшувало лінійні розміри рослин, збільшувало масу сирої та сухої речовини рослини. За впливу суміші ретардантів зростав вміст суми цукрів та зменшувався вміст крохмалю (Kasem \& Abd El-Baset, 2015). Ретарданти хлормекватхлорид і паклобутразол підвищували вміст сахарози в листках лілії (Zheng et al., 2012). Wang et al. (2016) встановили, що хлормекватхлорид пришвидшував відтік розчинних цукрів від листків до плодів у рослин кукурудзи та збільшував вміст білків у їх листках. Цей же ретардант збільшував вміст редукуючих цукрів і крохмалю у бульбах картоплі (Koteswara Rao et al., 2017). Зростання вмісту розчинних цукрів і амінокислот за дії хлормекватхлориду спостерігали також у саджанців гінкго дволопатевого (Zhang et al., 2013). Застосування препарату цикоцель на рослинах коноплі зумовлювало збільшення вмісту редукуючих цукрів у листках чоловічих рослин порівняно з контролем
(Sardoei et al., 2014). Цикоцель також збільшував загальний вміст цукрів за рахунок редукуючих форм у рослин винограду (Kumbar et al., 2017).

Вплив антигіберелінових препаратів пов'язаний із двома фізіологічними ефектами. Вони або інгібують синтез гібереліну триазолпохідні та онієві препарати (Rademacher, 2016), або ж блокують утворення гормон-рецепторного комплексу, тобто нівелюють вплив уже синтезованого гібереліну, - етиленпродуценти та гідразинпохідні сполуки (Zemlyanskaya et al., 2016).

Дія похідних триазолу на ріст осьових органів рослин пов'язана з пригніченням активності ент-кауренсинтетази та інгібуванням біосинтезу гіберелінів у трьох ланках цього процесу: на стадії перетворення геранілгераніолдифосфату в копалілпірофосфат і надалі в ент-каурен, як і деякі четвертинні амонієві солі (Radamacher, 2016). Крім цього, триазолпохідні препарати пригнічують перетворення ент-каурену в ент-кауренол, ент-кауренолу через ент-кауреналь в кауренову кислоту, що забезпечує надзвичайно високу та стабільну ретардантну активність стосовно росту стебла та проростання насіння багатьох рослин за рахунок пригнічення активності $\alpha$-амілази (Radamacher, 2016).

Дія етиленпродуцентів пов'язана з блокуванням утворення гормон-рецепторного комплексу. Тобто етилен запобігає сполученню гормона з рецептором, чим інгібує дію гіберелінової кислоти, i, як результат, пригнічує ростові процеси. Але, на відміну від онієвих препаратів, триазолів та дихлорізобутиратів, етиленпродуценти швидко розкладаються та мають коротший час дії (Radamacher, 2016).

Фотосинтетична продуктивність рослин упродовж вегетації вважається основою функціонування донорно-акцепторних відносин у системі «депо асимілятів - ріст». У рослин концепція донорно-акцепторних відносин визначається системою прямих i зворотних зв'язків (Yu et al., 2015), де процеси фотосинтезу слугують основним донором, а процеси росту та відкладання речовин у запас - акцепторами асимілятів (Kiriziy et al., 2014).

Під асимілятами мають на увазі різні сполуки асимільованого рослиною у процесі фотосинтезу вуглецю, у першу чергу транспортні та запасаючі форми вуглеводів, які вважають основою енергетичних і метаболічних процесів, а також «будівельним матеріалом» у процесах росту та розвитку на всіх рівнях організації рослинного організму (Kiriziy et al., 2014). Відомо також, що запасні речовини різних типів відіграють важливу роль буфера між фотосинтезом (як «джерелом» асимілятів) і ростом структурної речовини вегетативних, запасаючих і репродуктивних органів (як «стоком» асимілятів, що визначає певною мірою незалежність ростових процесів від фотосинтезу) (Singh et al., 2017).

Потужним «атрагувальним» центром в онтогенезі рослин виступає карпогенез - процес росту та формування плодів. При цьому використовують не лише новоутворені завдяки фотосинтезу вуглеводи, а і тимчасово депоновані у вегетативних органах 
цукри та крохмаль. Аналіз літературних даних свідчить, що під час застосування ретардантів у листках дослідних рослин утворюється більша кількість вуглеводів, які накопичуються та утворюють потужний резерв пластичних сполук, що використовуються для формування міцного стебла, закладання більшого числа плодів і поліпшення врожайності культури. Зростання продуктивності сільськогосподарських культур за впливу інгібіторів гібереліну відмічали на овочевих (Pavlista, 2013; Yooyongwech et al., 2017), плодових (Sarker et al., 2016), олійних (Hua et al., 2014; Sardoei et al., 2014) і зернобобових (Yan et al., 2015) культурах.

У літературі практично відсутні дані про порівняння впливу антигіберелінових препаратів із різним механізмом дії на депонувальну активність вегетативних органів. Тому мета цього дослідження - оцінити особливості накопичення та перерозподілу різних форм вуглеводів та азоту упродовж вегетації в рослинах, районованих для Лісостепу гібридах томатів Бобкат і Солероссо за дії тебуконазолу та есфону.

\section{Матеріал і методи досліджень}

Для вивчення впливу антигіберелінових препаратів тебуконазолу (EW-250) та есфону (2-ХЕФК) на морфогенез і продуктивність середньораннього детермінантного гібриду томатів голландської селекції Бобкат польові дрібноділянкові досліди закладали на землях СФГ «Бержан П.Г.» с. Горбанівка Вінницького району Вінницької області у вегетаційні періоди 2013-2015 років. Насіння томатів на розсаду висівали у парники 03.03.2013, 05.03.2014 i 10.03 .2015 р. Розсаду висаджували 08.05.2013, 10.05.2014 та 15.05 .2015 р. стрічковим способом за формулою $80+$ $50+50 \times 50$. Внесення мінеральних добрив $\mathrm{N}_{50} \mathrm{P}_{40} \mathrm{~K}_{30}$. Площа ділянок - $33 \mathrm{~m}^{2}$, повторність - п’ятикратна.

Вплив ретардантів на ріст, розвиток і урожайність гібриду томатів Солероссо вивчали польовим дрібноділянковим методом на землях СФГ «Сольський», с. Вінницькі Хутори Вінницького району Вінницької області у вегетаційні періоди 2015-2017 ро- ків. Насіння томатів ультрараннього детермінантного гібриду томатів голландської селекції Солероссо на розсаду висівали у парники 02.03.2015, 05.03.2016 i 12.03.2017 р. Розсаду висаджували $18.05 .2015,22.05 .2016$ і 27.05.2017 р. стрічковим способом за формулою $50+50+50 \times 50$. Внесення мінеральних добрив $\mathrm{N}_{50} \mathrm{P}_{40} \mathrm{~K}_{30}$. Площа ділянок - $33 \mathrm{~m}^{2}$, повторність - п'ятикратна.

Рослини обробляли вранці за допомогою ранцевого оприскувача ОП-2 до повного змочування листків $0,025 \%$ розчином тебуконазолу та $0,07 \%$ розчином есфону у фазу бутонізації 14.06.2013, 17.06.2014 та 19.06.2015 р. у рослин гібриду Бобкат та $0,025 \%$ розчином тебуконазолу та $0,05 \%$ розчином есфону у фазу бутонізації $06.06 .2015,16.06 .2016$ та 29.06 .2017 р. у рослин гібриду Солероссо. Контрольні рослини обприскували водою.

Фітометричні показники (висоту рослин, масу сухої речовини окремих органів та цілої рослини) визначали на 30 рослинах. Вміст цукрів і крохмалю визначали йодометричним методом, а вміст загального азоту - методом К'єльдаля. Повторюваність біохімічних досліджень - 15-кратна (АОАС, 2010). У тексті, таблицях і на графіках наведено середньоарифметичні значення та ïx стандартні похибки (SE). Результати обробляли статистично за допомогою програми Statistica 6.0. Застосовували однофакторний дисперсійний аналіз (відмінності між середніми значеннями обчислювали методом ANOVA, їх вважали вірогідними за $\mathrm{P}<0$,05) (Van Emden, 2008).

\section{Результати}

Ретардант тебуконазол і етиленпродуцент есфон зумовлювали зміни анатомо-морфологічних та біохімічних показників гібридів томатів Бобкат і Солероссо. Препарати гальмували лінійний ріст дослідних рослин. Найсуттєвіше зменшення висоти в обох гібридів спостерігали після застосування есфону (табл. 1). У гібриду Бобкат висота рослин була меншою, ніж у контролі, на $42,8 \%$, а у гібриду Солероссо - на $12,9 \%$. За дії тебуконазолу лінійні розміри рослин зменшувалися, відповідно, на $13,3 \%$ і 4,7\%.

\section{Таблиця 1}

Вплив есфону та тебуконазолу на листковий апарат рослин томатів гібридів Бобкат і Солероссо (фаза початку дозрівання плодів, середні дані за 2013-2015 роки у гібриду Бобкат і за 2015-2017 роки - у гібриду Солероссо; $\mathrm{n}=30, \mathrm{x} \pm \mathrm{SE}$ )

\begin{tabular}{|c|c|c|c|c|c|c|}
\hline \multirow{2}{*}{ Показник } & \multicolumn{3}{|c|}{ Гібрид Бобкат } & \multicolumn{3}{|c|}{ Гібрид Солероссо } \\
\hline & контроль & $0,07 \%$ есфон & 0,025\% тебуконазол & контроль & $0,05 \%$ есфон & 0,025\% тебуконазол \\
\hline Висота рослини, см & $67,5 \pm 1,82$ & $38,6 \pm 1,57 * *$ & $58,5 \pm 1,74^{* *}$ & $44,9 \pm 1,17$ & $39,1 \pm 1,09 * *$ & $42,8 \pm 1,14$ \\
\hline Кількість листків на рослині, шт. & $66,5 \pm 2,12$ & $53,2 \pm 1,75^{* *}$ & $73,3 \pm 2,47^{*}$ & $81,8 \pm 2,16$ & $97,9 \pm 2,23 * * *$ & $93,4 \pm 2,86^{* *}$ \\
\hline Маса сухої речовини листків, Г & $54,3 \pm 2,66$ & $31,2 \pm 1,32 * *$ & $59,1 \pm 2,81$ & $37,3 \pm 1,03$ & $32,5 \pm 0,86^{* *}$ & $43,3 \pm 1,25 * *$ \\
\hline Площа листків, см² & $11115 \pm 431$ & $6037 \pm 288^{* *}$ & $9878 \pm 407 *$ & $6975 \pm 162$ & $7605 \pm 189 *$ & $10226 \pm 291^{* *}$ \\
\hline
\end{tabular}

Примітка: ${ }^{*}-\mathrm{P}<0,05,{ }^{* *}-\mathrm{P}<0,01,{ }^{* * *}-\mathrm{P}<0,001$ порівняно $з$ контролем.

Листок - основний донор асимілятів, який постачає їх до всіх інших органів і прямо впливає на вміст вуглеводів у вегетативних і генеративних органах рослин. Аналіз кількісних показників, які характеризують листковий апарат, вказує на те, що тебуконазол зумовлює їх зростання. У гібриду Бобкат препарат збільшував кількість листків на рослині на 10,3\%, а масу сухої речовини листків - на 8,9\%. У гібриду Солероссо вказані показники зростали, відповідно, на 15,5\% і 16,2\% (табл. 1). Есфон достовірно зменшував у гібриду Бобкат як кількість листків, так i масу їх сухої речовини, тоді як у гібриду Солероссо кількість листків на рослині зростала, але маса їх сухої речовини достовірно зменшувалася. У томатів гібриду Бобкат обидва антигіберелінові препарати зменшували площу листкової поверхні, тоді як у гібриду Солероссо - збілышували, що можна пояснити сортовими особливостями цих рослин.

Зважаючи на зміни листкового апарату рослин томатів після обробки регуляторами росту, доцільно вивчити особливості накопичення та перерозподілу різних форм вуглеводів між органами рослин томатів в онтогенезі. Упродовж вегетаційного періоду спостерігали зменшення вмісту вуглеводів у вегетативних органах гібридів Бобкат і Солероссо як у контролі, так і у дослідних варіантах. Кількість цукрів зменшувалася за рахунок редукуючих форм. Одночасно відбувалося накопичення цукрів у плодах як у контролі, так і за обробки антигібереліновими препаратами. Вміст крохмалю при цьому постійно знижувався як у вегетативних, так і у генеративних органах (рис. 1).

У цілому, загальний вміст цукрів у корінні та стеблах став вищим у гібриду Солероссо, а у листках і плодах - у гібриду Бобкат. Гібрид Солероссо відзначався підвищеним вмістом сахарози в органах. У корінні гібриду Солероссо за дії есфону та тебуконазолу відбувалося накопичення цукрів і крохмалю в першій половині вегетації та посилений, порівняно 3 контролем, їх відтік - у другій. У гібриду Бобкат уміст цукрів на початку вегетації зменшувався, а наприкінці - практично не відрізнявся від контролю. Вміст крохмалю в корінні томатів гібриду Бобкат під час застосування обох препаратів суттєво перевищував контроль. Вищий вміст полісахариду зафіксований за обробки тебуконазолом.

Аналіз вмісту цукрів у стеблах гібриду Солероссо свідчить, що застосування антигіберелінових препаратів посилювало накопичення цукрів за рахунок переважно редукуючих форм у першій половині вегетації та інтенсифікувало їх відтік до плодів у другій. Найпоказовіше це відбувалося після обробки рослин тебуконазолом. Динаміка вмісту крохмалю у цього гібриду як у контролі, так і у варіантах із ретардантами не відзначалася стабільністю упродовж вегетації. 


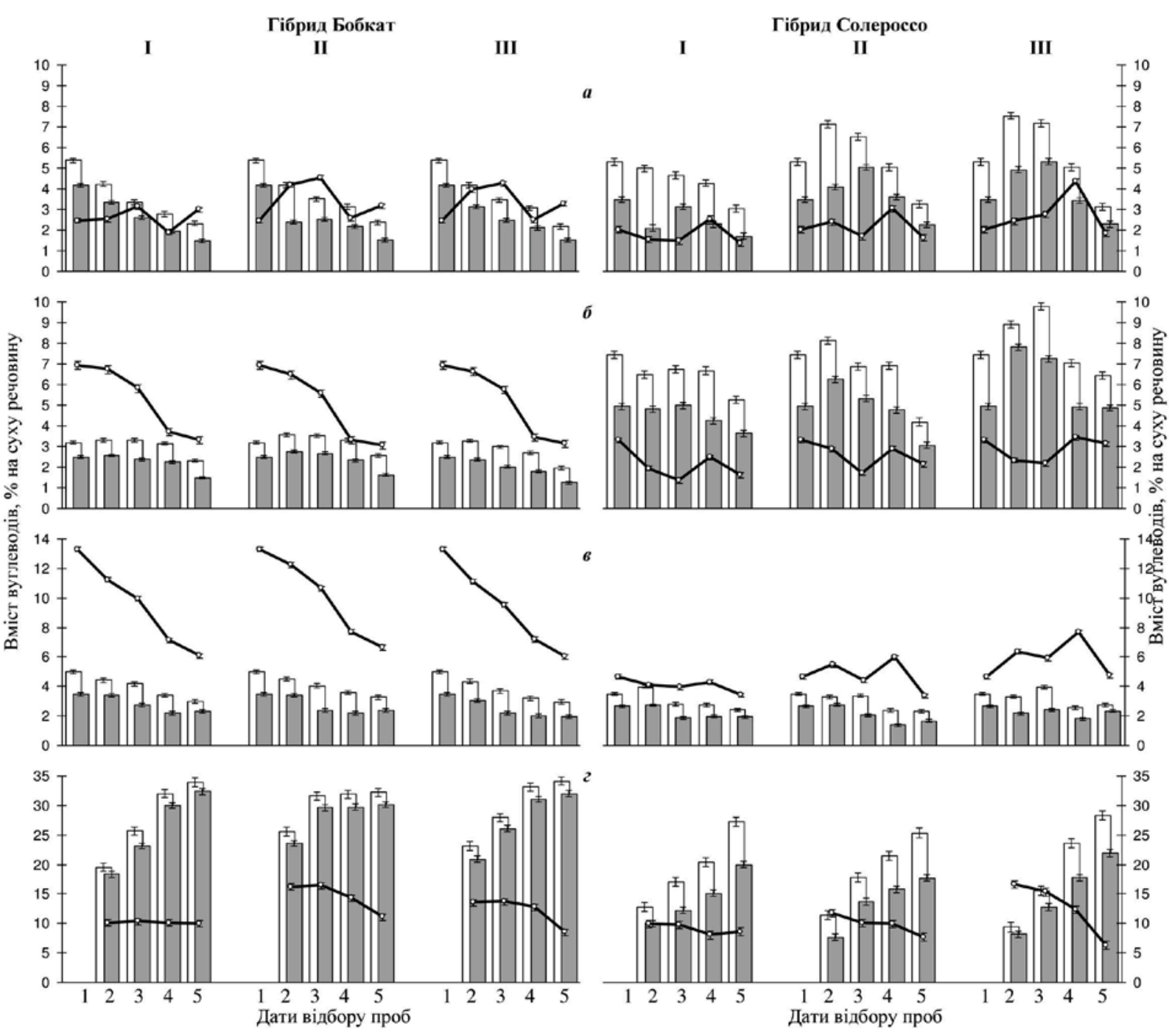

Рис. 1. Вплив антигіберелінових препаратів на вміст різних форм вуглеводів в органах рослин томатів гібридів Бобкат і Солероссо: середні трирічні дані за 2013-2015 роки у гібриду Бобкат і за 2015-2017 роки - у гібриду Солероссо; $\mathrm{n}=15, \mathrm{x} \pm \mathrm{SE}$; $a$ - коріння, $\sigma$ - стебла, 6 - листя, 2 - плоди; $I$ - контроль, $I I$ - есфон, $I I I$ - тебуконазол; 1 - дата обробки, 2 - 10-та, 3 - 20-та, 4 - 30-та, 5 - 40-ва доба після обробки; $\square$ - сума цукрів, $\square$ - редукуючі цукри, $\longrightarrow$ - крохмаль

У гібриду Бобкат есфон сприяв накопиченню цукрів у стеблах, а тебуконазол посилював їх відтік від осьового вегетативного органа до органів запасу. Вміст крохмалю у стеблах став меншим, ніж у контролі, а інгібітори росту посилювали його реутилізацію зі стебел.

Інгібітори гібереліну зменшували вміст цукрів у листках томатів гібриду Солероссо у фазу цвітіння та сприяли їх накопиченню у фазу закладання плодів. Під час формування плодів вміст цукрів у листках знову знижувався нижче контрольного за впливу як етиленпродуцента, так і триазолпохідного препарату. У цілому зафіксовано вищий вміст редукуючих цукрів та сахарози в листках після застосування тебуконазолу порівняно з есфоном і контролем. Антигіберелінові препарати посилювали накопичення крохмалю в листках на початку вегетаційного періоду та сповільнювали його відтік наприкінці. Найвищий уміст полісахариду зафіксовано в листках після застосування тебуконазолу.

Ми встановили зменшення вмісту цукрів у листках у досліді та контролі упродовж вегетації в гібриду Бобкат. На початку вегетації темпи реутилізації редукуючих цукрів із листків гібриду Бобкат були швидшими, а у другій половині уповільнилися, і навіть спостерігалося накопичення продуктів асиміляції за рахунок редукуючих форм цукрів після застосування есфону та за рахунок сахарози після обробки тебуконазолом. Під час вегетації відбувалася реутилізація крохмалю в листках. Есфон уповільнював цей процес у рослин томатів (на відміну від тебуконазолу та контролю, між якими за темпами гідролізу полісахариду достовірної різниці не зафіксовано).

Для розуміння процесів формування врожаю рослин томатів необхідно з'ясувати особливості накопичення та перерозподілу різних форм вуглеводів у плодах. Результати наших досліджень свідчать, що за дії тебуконазолу в обох гібридів томатів інтенсифікувався процес накопичення цукрів переважно за рахунок редукуючих форм. Після застосування есфону вміст цукрів і темпи ix накопичення стали нижчими за контрольні.

Інгібітори росту підвищували вміст крохмалю у плодах на початку вегетації та інтенсифікували його реутилізацію наприкінці. Найшвидше це відбувалося після обробки рослин томатів тебуконазолом незалежно від гібриду.

Упродовж вегетації прослідковувалася тенденція до зменшення відношення суми цукрів до крохмалю практично в усіх вегетативних органах обох гібридів томатів. Найсуттєвіше зменшення цього співвідношення зафіксоване після обробки томатів тебуконазолом. За впливу есфону показники не відзначалися стабільністю. Також у плодах дослідних рослин практично упродовж усього періоду вегетації спостерігали зниження співвідношення сума цукрів / крохмаль. У фазу появи зрілих плодів частка крохмалю в рослин, які зазнали дії ретардантів, була більшою, ніж у контролі (табл. 2). 
Таблиця 2

Вплив есфону та тебуконазолу на динаміку накопичення цукрів і крохмалю в органах томатів гібридів Бобкат і Солероссо (\% на суху речовину, середні дані за 2013-2015 роки у гібриду Бобкат і за 2015-2017 роки - у гібриду Солероссо, $\mathrm{n}=15, \mathrm{x} \pm \mathrm{SE}$ )

\begin{tabular}{|c|c|c|c|c|c|c|c|c|c|c|c|c|c|c|c|c|c|c|}
\hline \multirow{3}{*}{$\begin{array}{c}\text { Дата } \\
\text { від- } \\
\text { бору } \\
\text { проб }\end{array}$} & \multicolumn{9}{|c|}{ Гібрид Бобкат } & \multicolumn{9}{|c|}{ Гібрид Солероссо } \\
\hline & \multicolumn{3}{|c|}{ контроль } & \multicolumn{3}{|c|}{$0,07 \%$ есфон } & \multicolumn{3}{|c|}{ 0,025\% тебуконазол } & \multicolumn{3}{|c|}{ контроль } & \multicolumn{3}{|c|}{$0,05 \%$ есфон } & \multicolumn{3}{|c|}{$0,025 \%$ тебуконазол } \\
\hline & $\begin{array}{c}\text { сума } \\
\text { цукрів }\end{array}$ & охм. & $\begin{array}{l}\text { CЦ } \\
\mathrm{Kp} \\
\end{array}$ & $\begin{array}{c}\text { сума } \\
\text { цукрів }\end{array}$ & рохм. & $\begin{array}{l}\text { СЦ } \\
\text { Кр }\end{array}$ & $\begin{array}{c}\text { сума } \\
\text { цукрів }\end{array}$ & крохм. & $\begin{array}{l}\text { СЦ } \\
\text { Кр }\end{array}$ & $\begin{array}{c}\text { сума } \\
\text { цукрів }\end{array}$ & крохм. & $\begin{array}{l}\text { СЦ } \\
\text { Кр }\end{array}$ & $\begin{array}{c}\text { сума } \\
\text { цукрів }\end{array}$ & крохм. & $\begin{array}{l}\text { СЦ } \\
\text { Кр } \\
\end{array}$ & $\begin{array}{c}\text { сума } \\
\text { цукрів }\end{array}$ & крохм. & $\begin{array}{l}\mathrm{CЦ} \\
\mathrm{Kp} \\
\end{array}$ \\
\hline \multicolumn{19}{|c|}{ Коріння } \\
\hline 1 & $\begin{array}{r}4,23 \pm \\
0,106\end{array}$ & $\begin{array}{c}2,52 \pm \\
0,067\end{array}$ & 1,68 & $\begin{array}{c}4,18 \pm \\
0,105\end{array}$ & $\begin{array}{c}4,18 \pm \\
0,207^{* *}\end{array}$ & 1,00 & $\begin{array}{c}4,17 \pm \\
0,106\end{array}$ & $\begin{array}{c}3,95 \pm \\
0,169^{* *}\end{array}$ & 1,06 & $\begin{array}{r}4,98 \pm \\
0,125\end{array}$ & $\begin{array}{c}1,53 \pm \\
0,039\end{array}$ & 3,25 & $\begin{array}{c}7,14 \pm \\
0,279^{* *}\end{array}$ & $\begin{array}{c}2,37 \pm \\
0,105^{* *}\end{array}$ & 3,01 & $\begin{array}{c}7,54 \pm \\
0,289^{* *}\end{array}$ & $\begin{array}{c}2,43 \pm \\
0,164^{*}\end{array}$ & 3,10 \\
\hline 2 & $\begin{array}{l}3,34 \pm \\
0,084\end{array}$ & $\begin{array}{c}3,11 \pm \\
0,078\end{array}$ & 1,07 & $\begin{array}{c}3,51 \pm \\
0,088\end{array}$ & $\begin{array}{l}4,54 \pm \\
0,136^{* *}\end{array}$ & 0,77 & $\begin{array}{c}3,46 \pm \\
0,089\end{array}$ & $\begin{array}{l}4,25 \pm \\
0,109 *\end{array}$ & 0,81 & $\begin{array}{c}4,67 \pm \\
0,119\end{array}$ & $\begin{array}{l}1,47 \pm \\
0,037\end{array}$ & 3,18 & $\begin{array}{c}6,52 \pm \\
0,268 * *\end{array}$ & $\begin{array}{l}1,69 \pm \\
0,064^{*}\end{array}$ & 3,86 & $\begin{array}{c}7,18 \pm \\
0,283^{* *}\end{array}$ & $\begin{array}{c}2,75 \pm \\
0,169 *\end{array}$ & 2,61 \\
\hline 3 & $\begin{array}{c}2,78 \pm \\
0,071\end{array}$ & $\begin{array}{c}1,89 \pm \\
0,048\end{array}$ & 1,47 & $\begin{array}{l}3,13 \pm \\
0,079 *\end{array}$ & $\begin{array}{r}2,56 \pm \\
0,068\end{array}$ & 1,22 & $\begin{array}{l}3,07 \pm \\
0,077^{*}\end{array}$ & $\begin{array}{l}2,46 \pm \\
0,068^{*}\end{array}$ & 1,25 & $\begin{array}{c}4,28 \pm \\
0,109\end{array}$ & $\begin{array}{c}2,53 \pm \\
0,065\end{array}$ & 1,69 & $\begin{array}{l}5,04 \pm \\
0,128^{*}\end{array}$ & $\begin{array}{l}3,03 \pm \\
0,128^{*}\end{array}$ & 1,66 & $\begin{array}{l}5,03 \pm \\
0,129^{*}\end{array}$ & $\begin{array}{c}4,35 \pm \\
0,210^{* *}\end{array}$ & 1,16 \\
\hline 4 & $\begin{array}{r}2,32 \pm \\
0,058 \\
\end{array}$ & $\begin{array}{c}2,99 \pm \\
0,074 \\
\end{array}$ & 0,78 & $\begin{array}{r}2,38 \pm \\
0,063 \\
\end{array}$ & $\begin{array}{l}3,17 \pm \\
0,079 * * \\
\end{array}$ & 0,75 & $\begin{array}{c}2,17 \pm \\
0,054 \\
\end{array}$ & $\begin{array}{r}3,28 \pm \\
0,082 \\
\end{array}$ & 0,66 & $\begin{array}{r}3,03 \pm \\
0,079 \\
\end{array}$ & $\begin{array}{l}1,36 \pm \\
0,037 \\
\end{array}$ & 2,23 & $\begin{array}{c}3,26 \pm \\
0,087 \\
\end{array}$ & $\begin{array}{c}1,63 \pm \\
0,043^{* *}\end{array}$ & 2,00 & $\begin{array}{c}3,12 \pm \\
0,079 \\
\end{array}$ & $\begin{array}{c}1,83 \pm \\
0,049^{* *}\end{array}$ & 1,70 \\
\hline \multicolumn{19}{|c|}{ Стебла } \\
\hline 1 & $\begin{array}{c}3,31 \pm \\
0,085\end{array}$ & $\begin{array}{c}6,72 \pm \\
0,169\end{array}$ & 0,49 & $\begin{array}{c}3,56 \pm \\
0,089\end{array}$ & $\begin{array}{c}6,46 \pm \\
0,166\end{array}$ & 0,55 & $\begin{array}{c}3,28 \pm \\
0,083\end{array}$ & $\begin{array}{c}6,63 \pm \\
0,168\end{array}$ & 0,49 & $\begin{array}{c}6,49 \pm \\
0,167\end{array}$ & $\begin{array}{c}1,92 \pm \\
0,048\end{array}$ & 3,38 & $\begin{array}{c}8,14 \pm \\
0,208^{* *}\end{array}$ & $\begin{array}{c}2,85 \pm \\
0,107^{* *}\end{array}$ & 2,86 & $\begin{array}{c}8,91 \pm \\
0,322^{* *}\end{array}$ & $\begin{array}{c}2,31 \pm \\
0,059 *\end{array}$ & 3,86 \\
\hline 2 & $\begin{array}{c}3,29 \pm \\
0,083\end{array}$ & $\begin{array}{c}5,81 \pm \\
0,145\end{array}$ & 0,57 & $\begin{array}{c}3,51 \pm \\
0,088\end{array}$ & $\begin{array}{c}5,58 \pm \\
0,144\end{array}$ & 0,63 & $\begin{array}{c}2,98 \pm \\
0,077\end{array}$ & $\begin{array}{c}5,74 \pm \\
0,147\end{array}$ & 0,52 & $\begin{array}{c}6,73 \pm \\
0,169\end{array}$ & $\begin{array}{l}1,34 \pm \\
0,036\end{array}$ & 5,02 & $\begin{array}{c}6,88 \pm \\
0,177\end{array}$ & $\begin{array}{c}1,71 \pm \\
0,045^{* *}\end{array}$ & 4,02 & $\begin{array}{c}9,79 \pm \\
0,344^{* *}\end{array}$ & $\begin{array}{c}2,16 \pm \\
0,097^{*}\end{array}$ & 4,53 \\
\hline 3 & $\begin{array}{c}3,15 \pm \\
0,079\end{array}$ & $\begin{array}{c}3,69 \pm \\
0,099\end{array}$ & 0,85 & $\begin{array}{c}3,30 \pm \\
0,085\end{array}$ & $\begin{array}{l}3,31 \pm \\
0,089 *\end{array}$ & 1,00 & $\begin{array}{c}2,70 \pm \\
0,069^{*}\end{array}$ & $\begin{array}{c}3,43 \pm \\
0,089\end{array}$ & 0,79 & $\begin{array}{c}6,67 \pm \\
0,168\end{array}$ & $\begin{array}{r}2,46 \pm \\
0,066\end{array}$ & 2,71 & $\begin{array}{c}6,91 \pm \\
0,179\end{array}$ & $\begin{array}{l}2,89 \pm \\
0,074^{*}\end{array}$ & 2,39 & $\begin{array}{c}7,05 \pm \\
0,179\end{array}$ & $\begin{array}{c}3,42 \pm \\
0,109 *\end{array}$ & 2,06 \\
\hline 4 & $\begin{array}{c}2,32 \pm \\
0,058 \\
\end{array}$ & $\begin{array}{c}3,31 \pm \\
0,087 \\
\end{array}$ & 0,70 & $\begin{array}{c}2,57 \pm \\
0,067^{*}\end{array}$ & $\begin{array}{r}3,04 \pm \\
0,109 \\
\end{array}$ & 0,85 & $\begin{array}{l}1,95 \pm \\
0,049 *\end{array}$ & $\begin{array}{c}3,13 \pm \\
0,078 \\
\end{array}$ & 0,62 & $\begin{array}{c}5,27 \pm \\
0,132 \\
\end{array}$ & $\begin{array}{l}1,61 \pm \\
0,062 \\
\end{array}$ & 3,27 & $\begin{array}{l}4,19 \pm \\
0,109^{*}\end{array}$ & $\begin{array}{c}2,13 \pm \\
0,055^{* *}\end{array}$ & 1,97 & $\begin{array}{l}6,42 \pm \\
0,167^{*}\end{array}$ & $\begin{array}{l}3,11 \pm \\
0,148^{*}\end{array}$ & 2,06 \\
\hline \multicolumn{19}{|c|}{ Листя } \\
\hline 1 & $\begin{array}{c}4,43 \pm \\
0,111\end{array}$ & $\begin{array}{c}11,2 \pm \\
0,28\end{array}$ & 0,40 & $\begin{array}{c}4,51 \pm \\
0,115\end{array}$ & $\begin{array}{c}12,2 \pm \\
0,31\end{array}$ & 0,37 & $\begin{array}{c}4,35 \pm \\
0,109\end{array}$ & $\begin{array}{c}11,1 \pm \\
0,28\end{array}$ & 0,39 & $\begin{array}{c}3,98 \pm \\
0,101\end{array}$ & $\begin{array}{r}4,06 \pm \\
0,106\end{array}$ & 0,98 & $\begin{array}{l}3,27 \pm \\
0,086^{*}\end{array}$ & $\begin{array}{c}5,46 \pm \\
0,139 * *\end{array}$ & 0,60 & $\begin{array}{c}3,31 \pm \\
0,087^{* *}\end{array}$ & $\begin{array}{l}6,36 \pm \\
0,259^{*}\end{array}$ & 0,52 \\
\hline 2 & $\begin{array}{l}4,18 \pm \\
0,108\end{array}$ & $\begin{array}{c}9,93 \pm \\
0,248\end{array}$ & 0,42 & $\begin{array}{c}4,03 \pm \\
0,101\end{array}$ & $\begin{array}{c}10,6 \pm \\
0,27\end{array}$ & 0,38 & $\begin{array}{l}3,70 \pm \\
0,096^{*}\end{array}$ & $\begin{array}{c}9,52 \pm \\
0,239\end{array}$ & 0,39 & $\begin{array}{c}2,79 \pm \\
0,073\end{array}$ & $\begin{array}{c}3,95 \pm \\
0,101\end{array}$ & 0,71 & $\begin{array}{c}3,37 \pm \\
0,081^{* *}\end{array}$ & $\begin{array}{l}4,41 \pm \\
0,112^{*}\end{array}$ & 0,76 & $\begin{array}{l}3,95 \pm \\
0,179^{*}\end{array}$ & $\begin{array}{c}5,89 \pm \\
0,247^{*}\end{array}$ & 0,67 \\
\hline 3 & $\begin{array}{c}3,42 \pm \\
0,086\end{array}$ & $\begin{array}{c}7,10 \pm \\
0,179\end{array}$ & 0,48 & $\begin{array}{c}3,59 \pm \\
0,095\end{array}$ & $\begin{array}{c}7,68 \pm \\
0,199\end{array}$ & 0,47 & $\begin{array}{c}3,21 \pm \\
0,082\end{array}$ & $\begin{array}{c}7,19 \pm \\
0,187\end{array}$ & 0,45 & $\begin{array}{c}2,73 \pm \\
0,069\end{array}$ & $\begin{array}{c}4,28 \pm \\
0,209\end{array}$ & 0,64 & $\begin{array}{l}2,37 \pm \\
0,059^{*}\end{array}$ & $\begin{array}{l}5,95 \pm \\
0,249^{*}\end{array}$ & 0,40 & $\begin{array}{c}2,57 \pm \\
0,067\end{array}$ & $\begin{array}{c}7,67 \pm \\
0,359 *\end{array}$ & 0,34 \\
\hline 4 & $\begin{array}{c}2,99 \pm \\
0,751 \\
\end{array}$ & $\begin{array}{c}6,07 \pm \\
0,159 \\
\end{array}$ & 0,49 & $\begin{array}{c}3,26 \pm \\
0,082\end{array}$ & $\begin{array}{c}6,64 \pm \\
0,169 \\
\end{array}$ & 0,49 & $\begin{array}{c}2,95 \pm \\
0,074\end{array}$ & $\begin{array}{r}6,01 \pm \\
0,155 \\
\end{array}$ & 0,49 & $\begin{array}{r}2,41 \pm \\
0,064 \\
\end{array}$ & $\begin{array}{r}3,41 \pm \\
0,156 \\
\end{array}$ & 0,71 & $\begin{array}{c}2,33 \pm \\
0,059 \\
\end{array}$ & $\begin{array}{c}3,35 \pm \\
0,086 \\
\end{array}$ & 0,70 & $\begin{array}{l}2,74 \pm \\
0,069 *\end{array}$ & $\begin{array}{c}4,73 \pm \\
0,219 *\end{array}$ & 0,58 \\
\hline \multicolumn{19}{|c|}{ Плоди } \\
\hline 1 & $\begin{array}{c}19,5 \pm \\
0,491\end{array}$ & $\begin{array}{c}10,1 \pm \\
0,26\end{array}$ & 1,93 & $\begin{array}{c}25,6 \pm \\
0,641^{* *}\end{array}$ & $\begin{array}{l}16,2 \pm \\
0,421 * *\end{array}$ & 1,58 & $\begin{array}{l}23,1 \pm \\
0,781 *\end{array}$ & $\begin{array}{c}13,5 \pm \\
0,35 * *\end{array}$ & 1,71 & $\begin{array}{c}12,8 \pm \\
0,321\end{array}$ & $\begin{array}{l}9,87 \pm \\
0,349\end{array}$ & 1,30 & $\begin{array}{l}11,4 \pm \\
0,291^{*}\end{array}$ & $\begin{array}{c}11,7 \pm \\
0,391^{*}\end{array}$ & 0,97 & $\begin{array}{c}9,36 \pm \\
0,337^{*}\end{array}$ & $\begin{array}{c}16,6 \pm \\
0,737^{*}\end{array}$ & 0,56 \\
\hline 2 & $\begin{array}{c}25,7 \pm \\
0,641\end{array}$ & $\begin{array}{c}10,3 \pm \\
0,392\end{array}$ & 2,49 & $\begin{array}{c}31,6 \pm \\
0,791^{* *}\end{array}$ & $\begin{array}{l}16,4 \pm \\
0,721^{* *}\end{array}$ & 1,93 & $\begin{array}{c}27,9 \pm \\
0,69\end{array}$ & $\begin{array}{c}13,6 \pm \\
0,35^{* *}\end{array}$ & 2,05 & $\begin{array}{c}17,0 \pm \\
0,441\end{array}$ & $\begin{array}{c}9,74 \pm \\
0,248\end{array}$ & 1,75 & $\begin{array}{c}17,8 \pm \\
0,461\end{array}$ & $\begin{array}{c}10,0 \pm \\
0,271\end{array}$ & 1,78 & $\begin{array}{c}15,6 \pm \\
0,392\end{array}$ & $\begin{array}{c}15,3 \pm \\
0,638^{*}\end{array}$ & 1,02 \\
\hline 3 & $\begin{array}{l}32,0 \pm \\
0,810\end{array}$ & $\begin{array}{l}10,1 \pm \\
0,426\end{array}$ & 3,18 & $\begin{array}{c}31,9 \pm \\
0,792\end{array}$ & $\begin{array}{l}14,3 \pm \\
0,637^{* *}\end{array}$ & 2,24 & $\begin{array}{c}33,1 \pm \\
0,83\end{array}$ & $\begin{array}{c}12,7 \pm \\
0,32 * *\end{array}$ & 2,61 & $\begin{array}{c}20,4 \pm \\
0,532\end{array}$ & $\begin{array}{c}8,02 \pm \\
0,209\end{array}$ & 2,54 & $\begin{array}{c}21,5 \pm \\
0,552\end{array}$ & $\begin{array}{l}9,87 \pm \\
0,349^{*}\end{array}$ & 2,18 & $\begin{array}{l}23,6 \pm \\
0,611^{*}\end{array}$ & $\begin{array}{c}12,3 \pm \\
0,532 *\end{array}$ & 1,91 \\
\hline 4 & $\begin{array}{l}33,9 \pm \\
0,852 \\
\end{array}$ & $\begin{array}{c}9,92 \pm \\
0,249 \\
\end{array}$ & 3,42 & $\begin{array}{c}32,2 \pm \\
0,822 \\
\end{array}$ & $\begin{array}{l}11,1 \pm \\
0,279^{*}\end{array}$ & 2,90 & $\begin{array}{c}34,1 \pm \\
0,86 \\
\end{array}$ & $\begin{array}{l}8,52 \pm \\
0,213^{*}\end{array}$ & 4,00 & $\begin{array}{c}27,2 \pm \\
0,691 \\
\end{array}$ & $\begin{array}{c}8,59 \pm \\
0,217 \\
\end{array}$ & 3,16 & $\begin{array}{r}25,3 \pm \\
0,672 \\
\end{array}$ & $\begin{array}{c}7,64 \pm \\
0,194^{*} \\
\end{array}$ & 3,32 & $\begin{array}{r}28,3 \pm \\
0,732 \\
\end{array}$ & $\begin{array}{l}6,31 \pm \\
0,259 * \\
\end{array}$ & 4,48 \\
\hline
\end{tabular}

Примітки: * - Р < 0,05, ** - Р < 0,01, *** - P < 0,001 порівняно з контролем; 1 - 10-та, 2 - 20-та, 3 - 30-та, 4 - 40-ва доба після обробки; СЦ/Кр відношення суми цукрів (редукуючі цукри + нередукуючі цукри) до крохмалю.

Посилене накопичення вуглеводів плодами рослин томатів, що зазнали дії тебуконазолу, позитивно вплинуло на продуктивність культури. У гібриду Бобкат сира маса одного плоду після обробки триазолпохідним препаратом на кінець досліджуваного періоду перевищувала контрольний показник (153 $\pm 3,3$ г) на 5,6\% $(161 \pm 4,0$ г). У гібриду Солероссо тебуконазол зумовив зростання середньої маси одного плоду на $23,1 \%(51,2 \pm 1,2$ г) порівняно 3 контролем $(41,5 \pm 1,1$ г). За дії есфону показники практично не відрізнялася від контролю. Результати свідчать, що упродовж вегетації відбувалося зменшення вмісту загального азоту у вегетативних органах як у контролі, так і в досліді в обох гібридів томатів (рис. 2). Лише у корінні контрольного варіанта відбувалося накопичення цього елемента або ж його вміст у першій половині вегетації суттєво не змінювався.

Обробка тебуконазолом посилювала відтік азоту від коріння та стебел. Інтенсивніше азот виносився з осьових органів у гібриду Бобкат. У фазу формування плодів цей показник став нижчим контрольного на 19,4\% у корінні та 18,0\% у стеблах, тоді як у гібриду Солероссо у цю ж фазу вегетації він відповідно знижувався на $10,7 \%$ та $11,1 \%$. Препарат уповільнював відтік азоту 3 листків порівняно з контролем. У даному випадку повільніше це відбувалося в гібриду Солероссо. Під час фази активного формування плодів у листках гібриду Солероссо вміст азоту перевищував контроль на 12,9\%, тоді як у гібриду Бобкат - на 9,2\%.

Етиленпродуцент есфон по-різному впливав на динаміку загального азоту в осьових органах гібридів Бобкат і Солероссо.
За його дії у гібриду Бобкат відбувався відтік елемента з коріння та накопичення його у стеблі. У гібриду Солероссо, навпаки, спостерігалося накопичення азоту в корінні та інтенсивний його відтік від стебел, особливо у другій половині вегетації. В обох гібридів томатів есфон сповільнював відтік азоту з листків. На кінець періоду досліджень вміст загального азоту в гібриду Солероссо перевищував контроль на 14,5\%, а у гібриду Бобкат - на 8,9\%.

Аналіз динаміки азоту у плодах свідчить, що у томатів гібриду Бобкат відбувалося накопичення цього елемента упродовж вегетаційного періоду. Ретарданти уповільнювали процес накопичення азоту плодами. Зокрема, на кінець досліджуваного періоду вміст загального азоту за обробки есфоном знижувався на $19,9 \%$, а після застосування тебуконазолу - на 5,2\%. У гібриду Солероссо відбувалося постійне зниження вмісту азоту у плодах як у досліді, так і в контролі. Тебуконазол уповільнював процес реутилізації азоту. На кінець досліджень його вміст став більшим на 5,5\%, ніж у контролі. За дії есфону показник практично не відрізнявся від контролю. Посилення відтоку азоту від вегетативних органів до плодів за дії тебуконазолу збільшило кількість плодів на рослині. У гібриду Бобкат за дії триазолпохідного препарату показник зріс на 21,3\% (12,6 $\pm 0,33$ шт.) порівняно 3 контролем (10,0 \pm 0,18 шт.). У гібриду Солероссо кількість плодів на рослині зросла порівняно з контролем (35,4 $\pm 1,07$ шт.) на $2,8 \%$ (36,4 $\pm 1,29$ шт.).

Зміна швидкості ростових процесів за впливу антигіберелінових препаратів суттєво вплинула на листковий апарат дослід- 
них рослин. Зміни морфометричних характеристик листків як донорів асимілятів зумовили зміни накопичення та перерозподіл різних форм вуглеводів і загального азоту. Обробка регуляторами росту пришвидшувала процеси реутилізації різних форм цукрів і азоту.

\section{Обговорення}

Регуляція донорно-акцепторних відносин у системі цілої рослини здійснюється через координацію фотосинтезу та ростової функції, причому будь-які природні або експериментальні зміни швидкості ростових процесів супроводжуються адекватною перебудовою фотосинтетичного апарату. Застосування інгібіторів гібереліну дозволяє змінювати темпи росту тих або інших органів рослини, внаслідок чого можливий перерозподіл потоків асимілятів до господарсько-важливих тканин і органів.

Зменшення запиту на асиміляти після застосування ретардантів і етиленпродуцентів створює ефект їх надлишку у рослині, який спрямовується на посилений ріст бічних органів і органів запасання. Зафіксоване нами явище пригнічення ростових процесів в осьових органах томатів супроводжувалося зростанням кількісних показників листкового апарату. Схожі ефекти за впливу паклобутразолу зафіксовано на рослинах батату (Үооyongwech et al., 2017), за дії уніконазолу на рослинах соєвих бобів (Yan et al., 2015), після обробки хлормекватхлоридом у рослин пажитниці багаторічної (Kasem \& Abd El-Baset, 2015).
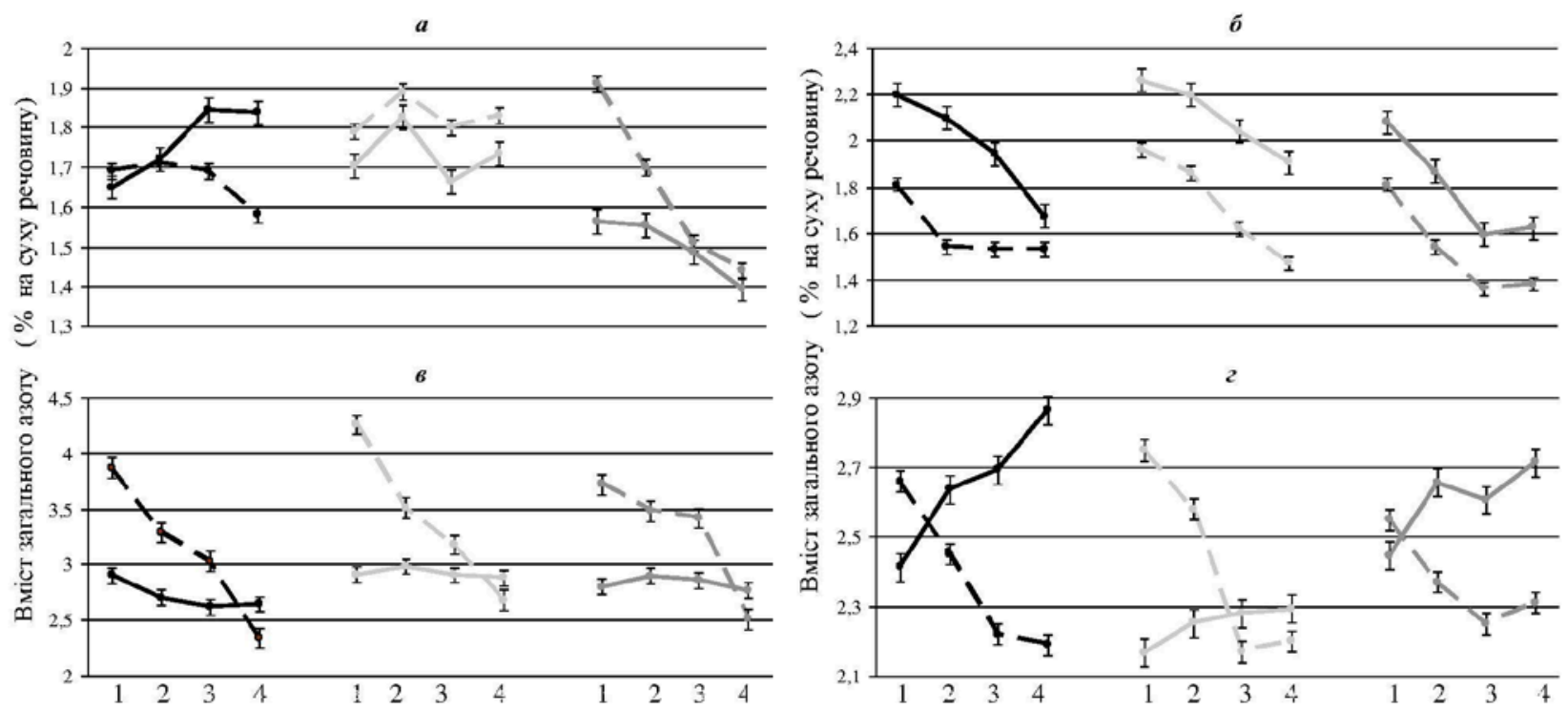

Рис. 2. Вплив антигіберелінових препаратів на вміст загального азоту в органах томатів гібридів Бобкат і Солероссо (середні дані за 2013-2015 роки у гібриду Бобкат і за 2015-2017 роки у гібриду Солероссо, $\mathrm{n}=15, \mathrm{x} \pm \mathrm{SE}$ ): $a$-коріння, б - стебла; в - листя; 2 - плоди; 1 - 10-та, 2 - 20-та, 3 - 30-та, 4 - 40-ва доба після обробки; _ - гібрид Бобкат, - _ - гібрид Солероссо

Зростання кількості листків, маси їх сухої речовини та площі листкової поверхні сприяє підвищенню фотосинтетичної продуктивності рослини, що одночасно посилюється зменшенням їх витрат на ростові процеси з наступним перерозподілом до інших тканин і органів рослин. У зв'язку із цим, важливо встановити напрямок переміщення пластичних речовин у рослині. Як свідчать результати наших досліджень, упродовж вегетації вміст цукрів і крохмалю у вегетативних органах томатів постійно зменшувався, а у плодах зростав за рахунок цукрів, а саме редукуючих форм. Такі зміни динаміки цілком узгоджуються із загальною концепцією функціонування рослинного організму «джерело - стік».

Гальмування лінійного росту ретардантами зумовило зростання вмісту вуглеводів у вегетативних органах рослин томатів порівняно з контролем. Надлишок пластичних речовин, що накопичився у першій половині вегетації за впливу препаратів, активніше транспортується до плодів. Саме із цим можна пов'язати посилення реутилізації крохмалю як у вегетативних, так і у генеративних органах упродовж усього вегетаційного періоду в обох гібридів томатів. Підтвердженням цього явища вважаємо постійне зменшення співвідношення вмісту цукрів до крохмалю в усіх органах рослин. Аналогічне посилення відтоку цукрів із листків до плодів відбувалося за дії хлормекватхлориду у рослин кукурудзи (Wang et al., 2016). Зростання вмісту вуглеводів у вегетативних і генеративних органах рослин за дії ретардантів відмічали й інші дослідники. Паклобутразол збільшував уміст суми цукрів у батату (Yooyongwech et al., 2017), манго (Sarker et al., 2016), рису (Xiang et al., 2017), каноли (Hua et al., 2014). Хлормекватхлорид зумовлював зростання загального вмісту цукрів у пажитниці багаторічної (Kasem \& Abd El-Baset, 2015), вміст ca- харози - у лілії (Zheng et al., 2012), вміст цукрів і крохмалю - у бульбах картоплі (Koteswara Rao et al., 2017).

Результати наших досліджень свідчать, що блокування утворення гормон-рецепторного комплексу в рослин томатів за впливу етиленпродуценту есфону мало сильніший рістгальмівний ефект, ніж переривання синтезу гібереліну у трьох ланках за дії ретарданту тебуконазолу. На нашу думку, надмірне гальмування ростових процесів за дії есфону спричинило також пригнічення процесів транспортування речовин по рослині, що в кінцевому підсумку спричинило зменшення вмісту цукрів у плодах і негативно вплинуло на продуктивність культури. Це пов'язано з тим, що достатне забезпечення зони плодів цукрами сприятиме їх перетворенню на структурні полісахариди, які беруть участь у карпогенезі.

У той же час за впливу тебуконазолу відбувалося помірне гальмування лінійного росту та процесів транспорту речовин по рослині, що створило надлишок пластичних речовин, які активно надходили до плодів і брали участь у процесах карпогенезу. Формування надлишку цукрів забезпечувалося не лише фотосинтетичними процесами та меншим їх використанням на ростові процеси, а й унаслідок посилення гідролізу крохмалю у вегетативних органах томатів за впливу тебуконазолу.

У науковій літературі міститься інформація про підвищення продуктивності сільськогосподарських культур за впливу інших триазолпохідних препаратів. Зокрема, застосування паклобутразолу підвищувало продуктивність батату (Yooyongwech et al., 2017), манго (Sarker et al., 2016), каноли (Hua et al., 2014), а уніконазол сприяло зростанню урожайності соєвих бобів (Yan et al., 2015).

Під час вегетації відбувається зменшення вмісту азоту у вегетативних органах внаслідок його відтоку до квітів, плодів і на- 
сіння, а також використання на ростові процеси в рослині в цілому. Результати дозволяють констатувати, що закладання та формування більшої кількості плодів за впливу тебуконазолу викликало посилення відтоку цього елемента 3 коріння та стебел до генеративних органів. Зростання вмісту загального азоту в листках, на нашу думку, вважається підтвердженням кращого забезпечення донора асимілятів ферментативним апаратом, що вважаємо додатковим фактором активізації фотосинтетичних процесів за впливу ретарданту. Зменшення вмісту азоту у плодах рослин томатів гібриду Солероссо упродовж вегетаційного періоду за впливу ретардантів пов'язане, очевидно, з біорозбавленням елементу внаслідок закладання та формування значної кількості плодів, у той час коли в гібриду Бобкат плодів закладалося практично втричі менше, що стало причиною накопичення азоту.

Застосування тебуконазолу сприяло формуванню донорної сфери рослин томатів, посиленню їх асиміляційного потенціалу, тимчасовому депонуванню фотоасимілятів і азотумісних сполук у вегетативних органах рослини з наступною активною реутилізацією цих сполук на потреби закладання, формування та росту плодів. Наслідком такої перебудови донорно-акцепторної системи рослини вважаємо підвищення врожаю культури томатів за дії цього препарату. Надмірне гальмування ростових і обмінних процесів у рослин томатів за впливу есфону зумовило зниження продуктивності культури, незважаючи на цілу низку позитивних морфометричних, фізіологічних та біохімічних ефектів, які проявилися після застосування препарату.

\section{Висновки}

Антигіберелінові препарати з різним механізмом дії, тебуконазол і есфон, викликали зміни ростових процесів листковому апараті, накопиченні та перерозподілі різних форм вуглеводів і загального азоту у вегетативних і генеративних органах гібридів томатів Бобкат і Солероссо. Обидва препарати зменшували лінійні розміри рослин томатів та збільшували кількість листків на рослинах. Суха речовина листків зростала лише після застосування тебуконазолу, а площа листків за дії інгібіторів гібереліну збільшувалася в гібриду Солероссо та зменшувалася у гібриду Бобкат.

У процесі вегетації відбувалося зменшення вмісту вуглеводів у вегетативних органах обох гібридів томатів як у контролі, так і в досліді з одночасним накопиченням цукрів у плодах. Вміст цукрів змінювався переважно за рахунок редукуючих форм. Гібрид Солероссо відзначався вищим умістом сахарози в органах.

Інгібітори росту посилювали відтік цукрів та знижували вміст крохмалю в корінні та стеблах обох гібридів томатів. У листках гібриду Солероссо вміст крохмалю, редукуючих і нередукуючих цукрів став вищим після застосування тебуконазолу. У гібриду Бобкат есфон зумовлював збільшення вмісту редукуючих форм цукрів, а тебуконазол - нередукуючих.

Тебуконазол посилював накопичення цукрів у плодах за рахунок редукуючих форм в обох гібридів томатів, тоді як есфон знижував їх вміст порівняно з контролем. Інгібітори росту підвищували вміст крохмалю у плодах на початку вегетації та інтенсифікували його реутилізацію наприкінці. Найшвидше це відбувалося після обробки рослин томатів тебуконазолом незалежно від гібриду. Упродовж вегетації спостерігали чітку тенденцію до зменшення відношення суми цукрів до крохмалю практично в усіх органах обох гібридів томатів. Найсуттєвіше зменшення цього співвідношення зафіксоване після обробки рослин тебуконазолом, що свідчить про посилене накопичення вуглеводів плодами за дії ретарданту. Це сприяло у подалышому зростанню середньої маси одного плоду. Під час вегетації відбувалося зменшення вмісту загального азоту у вегетативних органах як у контролі, так і в досліді в обох гібридів томатів. Тебуконазол пришвидшував відтік загального азоту 3 коріння та стебел і збілышував його вміст у листках. За дії триазолового препарату відбувалося уповільнення накопичення цього елемента у плодах. Такі зміни у динаміці загального азоту за впливу тебуконазолу зумовили посилену закладку плодів на рослинах томатів.

\section{References}

AOAC (2010). Official methods of analysis of association of analytical chemist international. 18th ed. Association of Analytical Chemist. Gaithersburg, Maryland, USA.

Hegde, S., Adiga, J. D., Honnabyraiah, M. K., Guruprasad, T. R., Shivanna, M., \& Halesh, G. K. (2018). Influence of paclobutrazol on growth and yield of jamun cv. Chintamani. International Journal of Current Microbiology and Applied Sciences, 7(1), 1590-1599.

Kasem, M. M., \& Abd El-Baset, M. M. (2015). Studding the influence of some growth retardants as a chemical mower on ryegrass (Lolium perenne L.). Journal of Plant Sciences, 3(5), 255-258.

Kiriziy, D. A., Stasyk, O. O., Pryadkina, G. A., \& Shadchyna, T. M. (2014). Photosynthesis. T.2. Assimilation of $\mathrm{CO}_{2}$ and mechanisms of its regulation. Logos, Kyiv (in Russian).

Koteswara Rao, G., Surendra Babu, M., Nagaraju, M. M., Thomson, T., Ranganna, G., \& Siva, M. (2017). A critical review on effect of plant growth regulators on root vegetables. International Journal of Current Microbiology and Applied Sciences, 6(7), 1243-1247.

Kumbar, S., Patil, D. R., Das, K. K., Swamy, G. S. K., Thammaiah, N., Jayappa, J., \& Gandolkar, K. (2017). Studies on the influence of growth regulators and chemicals on the quality parameters of grape $\mathrm{cv}$. $2 \mathrm{~A}$ Clone. International Journal of Current Microbiology and Applied Sciences, 6(5), 2585-2592.

Liu, L., Fang, Y., Huang, M., Jin, Y., Sun, J., Tao, X., Zhang, G., He, K., Zhao, Y., \& Zhao, H. (2014). Uniconazole-induced starch accumulation in the bioenergy crop duckweed (Landoltia punctata) II: transcriptome alterations of pathways involved in carbohydrate metabolism and endogenous hormone crosstalk. Biotechnologie for Biofuels, 8, 64.

Pavlista, A. D. (2013). Influence of foliar-applied growth retardants on russet burbank potato tuber production. American Journal of Potato Research, 90, 395-401.

Rademacher, W. (2016). Chemical regulators of gibberellin status and their application in plant production. Annual Plant Reviews, 49, 359-403.

Sardoei, A. S., Yazdi, M. R., \& Shshdadneghad, M. (2014). Effect of cycocel on growth retardant cycocel on reducing sugar, malondialdehyde and other aldehydes of Cannabis sativa L. International Journal of Biosciences, 4(6), 127-133.

Sarker, B. C., Rahim, M. A., \& Archbold, D. D. (2016). Combined effects of fertilizer, irrigation, and paclobutrazol on yield and fruit quality of mango. Horticulturae, 2, 14.

Singh, S. K., Nath, V., Marboh, E. S., \& Sharma, S. (2017). Source-sink relationship in litchi verses mango: A concept. International Journal of Current Microbiology and Applied Sciences, 6(3), 500-509.

Van Emden, H. F. (2008). Statistics for terrified biologists. Blackwell, Oxford.

Wang, Y., Gu, W., Xie, T., Li, L., Sun, Y., Zhang, H., Li, J., \& Wei, S. (2016). Mixed compound of DCPTA and CCC increases maize yield by improving plant morphology and upregulating photosynthetic capacity and antioxidants. PLoS One, 11(2), e0149404.

Xiang, J., Wu, H., Zhang, Y., Zhang, Y., Wang, Y., Li, Z., Lin, H., Chen, H., Zhang, J., \& Zhu, D. (2017). Transcriptomic analysis of gibberellin- and paclobutrazol-treated rice seedlings under submergence. International Journal of Molecular Sciences. 18, 2225.

Yan, Y., Wan, Y., Liu, W., Wang, X., Yong, T., \& Yang, W. (2015). Influence of seed treatment with uniconazole powder on soybean growth, photosynthesis, dry matter accumulation after flowering and yield in relay strip intercropping system. Plant Production Science, 18(3), 295-301.

Yooyongwech, S., Samphumphuang, T., Tisarum, R., Theerawitaya, C., \& Cha-um S. (2017). Water-deficit tolerance in sweet potato [Ipomoea batatas (L.) Lam.] by foliar application of paclobutrazol: Role of soluble sugar and free proline. Frontiers in Plant Science, 8, 1400.

Yu, S. M., Lo, S. F., \& Ho, T. D. (2015). Source-sink communication: Regulated by hormone, nutrient, and stress cross-signaling. Trends in Plant Science, 20(12), 844-857.

Zemlyanskaya, E. V., Omelyanchuk, N. A., Ermakov, A. A., \& Mironova V. V. (2016). Mekhanizmy rehuliatsyi peredachi etylenovoho sihnala u rastenii [Regulatory mechanisms tuning ethylene signaling in plants]. Vavilovskii Zhurnal Henetiki i Selektsyi, 20(3), 386-395 (in Russian).

Zhang, W., Xu, F., Hua, C., \& Cheng, S. (2013). Effect of chlorocholine chloride on chlorophyll, photosynthesis, soluble sugar and flavonoids of Ginkgo biloba. Notulae Botanicae Horti Agrobotanici Cluj-Napoca, 41(1), 97-103.

Zheng, R., Wu, Y., \& Xia, Y. (2012). Chlorocholine chloride and paclobutrazol treatments promote carbohydrate accumulation in bulbs of Lilium Oriental hybrids "Sorbonne”. Journal of Zhejiang University. Science B (Biomedicine and Biotechnology), 13(2), 136-144. 